\title{
Formation of Macroaggregates and Organic Carbon in Cocoa Agroforestry Systems
}

\author{
Leonardo Rodríguez Suárez ${ }^{1}$ (D), Leidy Carolina Ule Audor ${ }^{1}$ (D), \\ Juan Carlos Suárez Salazar ${ }^{1}$ \\ ${ }^{1}$ Programa de ingeniería agroecológica, Universidad de la Amazonia, Florencia / Caquetá, Colombia
}

\begin{abstract}
The objective of this study was to analyze the biological contribution to macroaggregate formation under cocoa agroforestry systems, as well as to evaluate the potential of macroaggregates to store carbon. The variation of the populations of macrofauna and the relationship with the morphology of aggregates was monitored in five agroforestry systems associated with cocoa established from different land uses, taking as reference the forest and pasture. Some cacao agroforestry systems favored the presence of macrofauna functional groups similar to the forest $(\mathrm{p}<0.05)$. According to the principal component analysis, the effect of land use on macroaggregate formation is highly significant $(\mathrm{p}<0.001)$ and explained $55 \%$ of the total variance. The macrofauna and macroaggregates showed significant covariation $(\mathrm{RV}=0.22$, $\mathrm{p}$-value $=0.001)$. Biogenic macroaggregates contained more carbon when they came from agroforestry systems.
\end{abstract}

Keywords: soil macrofauna, functional groups, co-inertia analysis. 


\section{INTRODUCTION}

Cocoa (Theobroma cacao L.) is one of the most economically important tropical crops, which can be managed under agroforestry systems (Suárez et al., 2018). In this association, besides providing shade and climate regulation to the crop, other environmental benefits related to the improvement of edaphic properties are provided (Vanhove et al., 2016; Wartenberg et al., 2017). Soil aggregation is among the edaphic properties improved by modifying the management conditions of the crop under agroforestry systems (Chen et al., 2017).

Aggregates are the basic units of soil structure. They regulate ecological functions such as water dynamics in soil, soil porosity, soil organic matter, soil susceptibility to erosion, and nutrient dynamics (Chen et al., 2017). Soil aggregates can be formed as a result of the physical forces in the wetting and drying cycle, the compression by roots and the interaction of the macrofauna with the organ-mineral phase of the soil (Silva et al., 2016). At a functional level, soil aggregates play a vital role in the long-term preservation and storage of organic carbon in the soil (Acar et al., 2018). However, this function depends mainly on efficient soil coverage, such as in agroforestry systems (Chen et al., 2017).

By implementing cocoa under the agroforestry systems, the formation of soil aggregates can be modified (Silva et al., 2016), especially the biogenic aggregates, since a continuous intake of plant residues is guaranteed in quantity and quality, benefitting the macrofauna groups (Moço et al., 2009). These macrofauna groups act mainly on soil structure through bioturbation (Lavelle et al., 2016), creating structures enriched with organic carbon and nutrients (Lubbers et al., 2017).

In this study, the macrofauna and the different soil aggregates were evaluated, as well as their organic carbon content, under different agroforestry cocoa systems. The systems varied according to their composition, structure, and time of implementation. According to Silva et al. (2016), related studies on the formation of different types of soil aggregates allow not only to understand their dynamics and the associated processes, but also to obtain an integral vision of soil quality. The use of a visual method of aggregate morphology is one way of evaluating soil structure and specifically aggregation (Lavelle et al., 2014), which successfully determines soil structure under different uses and management strategies. Therefore, the objective of this study was to analyze the biological contribution to the formation of soil aggregates under cocoa agroforestry systems and to evaluate their potential in carbon storage.

\section{MATERIAL AND METHODS}

\subsection{Study area and soil use}

The study was performed at the Amazonas Macagual Research Center - César Augusto Estrada González, located west from the Colombian Amazon (1³0'4.87” N and $\left.75^{\circ} 39^{\prime} 47.16^{\prime \prime} \mathrm{W}\right)$. This Center is located in a humid area with an average annual precipitation of 3,793 $\mathrm{mm}$ and a monomodal rainfall. The maximum precipitation is distributed between April and September, with solar brightness of 1,707 hours/year, average temperature of $25.5^{\circ} \mathrm{C}$ and relative humidity of $84.3 \%$ (IGAC, 2014). The macrofauna and soil aggregates were collected in five agroforestry systems associated with cocoa established from different soil uses that were compared, taking the forest and pasture as references. All cocoa agroforestry systems were implemented in October 2013 at a planting density of $3.5 \times 3.5 \mathrm{~m}$ between plants and $5 \mathrm{~m}$ of street with different timber species as shade (Huito Genipa americana L., Caracolí Osteophloeum platyspermum (A.DC.) Warb., Abarco Cariniana pyriformis Miers and Capirón Calycophyllum spruceanum (Benth.) K.Schum.), sown at $9 \times 9 \mathrm{~m}$ between trees. The description of the different coverages the cocoa crop established is shown in Table 1.

\subsection{Characterization of edaphic properties}

A soil sample was taken in each plot of the five agroforestry systems associated with cocoa and in the reference coverages (forest and pasture), composed of six subsamples, at $30 \mathrm{~cm}$ depth. The following physical and chemical determinations were made following the methodologies described by Zamudio et al. (2006): textural class (Bouyoucos); bulk density (cylinder method of known volume); particle density (pyknometer method); total porosity (relation between bulk density and particle density); soil moisture (relationship between water mass and soil mass, once dried); soil penetration resistance (analogue hand penetrometer); chemical properties such as $\mathrm{pH}$ (potentiometer method in water: soil ratio: water of 1:2), organic carbon (Walkley-Black method), total nitrogen (Kjeldahl), exchangeable acidity (volumetric), exchangeable aluminum by 
Table 1. Description of the systems associated with cocoa and in the reference coverages (forest and pasture).

\begin{tabular}{|c|c|}
\hline Soil use & Description \\
\hline Forest & A natural system without any anthropic intervention. \\
\hline AFS 1 & $\begin{array}{l}\text { It was established from the stubble of } 15 \text { years. In the cleaning process, trees of the species Guamo } \\
\text { (Inga edulis Mart.), Capirona (Capirona decorticans Spruce), Aceituno (Vitex klugii Moldenke) and Paricá } \\
\text { (Schizolobium amazonicum) were preserved, a product of natural regeneration. }\end{array}$ \\
\hline AFS 2 & $\begin{array}{l}\text { It was established from the stubble of } 15 \text { years. In the process of cleaning, trees of the species Guamo } \\
\text { (Inga edulis Mart.), Laurel (Ocotea longifolia Kunth) and Chingale (Jacaranda copaia (Aubl.) D.Don.) were } \\
\text { preserved, a product of natural regeneration. }\end{array}$ \\
\hline AFS 3 & It was established on the stubble of 7 years, eliminating all the coverage of the trees. \\
\hline AFS 4 & $\begin{array}{l}\text { It was established from the stubble of } 7 \text { years. In the process of cleaning, trees of the species Chontaduro } \\
\text { (Bactris gasipaes Kunth) were preserved. }\end{array}$ \\
\hline AFS 5 & The system was established from a degraded pasture with 8 years of use. \\
\hline Pasture & The conventional system was composed of Brachiaria decumbens and Brachiaria humidicola grasses. \\
\hline
\end{tabular}

titration difference of acidity interchangeable hydrogen, cation exchange capacity (extraction with $1 \mathrm{~N}$ and neutral ammonium acetate), phosphorus (modified Bray II method), and total bases ( $\mathrm{Ca}, \mathrm{Mg}, \mathrm{Na}$ and $\mathrm{K}$ ) (extraction with $1 \mathrm{~N}$ ammonium acetate and neutral atomic absorption spectrophotometry).

\subsection{Extraction of the macrofauna from the soil}

To quantify the macrofauna, the ISO 23611-5 standard was followed. Six monoliths $(25 \times 25 \mathrm{~cm}$ blocks with $10 \mathrm{~cm}$ of depth) were collected in each evaluated agroforestry system. The soil contained in each monolith was verified manually in situ. The soil macrofauna was preserved in 70\% alcohol, separated in the laboratory according to its morphology and identified up to class or order.

\subsection{Evaluation of the morphology of soil aggregates}

The visual method proposed by Velásquez et al. (2007) was used. Six monoliths $(10 \times 10 \times 10 \mathrm{~cm})$ were collected next to the monolith for macrofauna. Then the entire volume of soil collected in the monolith was manually separated in different categories, with the help of a magnifying glass when necessary. The sample passed through sieves with different mesh sizes to separate each category according to their size (macroaggregate $>5 \mathrm{~mm}$ and non-macroaggregated fraction $<5 \mathrm{~mm}$ ) in different components such as:

i. Biogenic macroaggregates $\left(\mathrm{Bio}_{\text {Macro }}\right)$ formed by soil fauna, with dense and rounded forms and clear evidence of biological activity (galleries, casts, structures); ii. Physical macroaggregates $\left(\right.$ Phys $_{\text {Macro }}$ ) formed by physical processes, with geometric shapes (wetting and drying cycle);

iii. Root macroaggregates ( Root $_{\mathrm{Macro}}$ ) is the result of the interaction between root system and soil aggregates;

iv. Non-macroaggregate fraction $\left(\mathrm{Non}_{\mathrm{Macro}}\right)$, soil particles and unidentified aggregates smaller than $5 \mathrm{~mm}$.

Organic matter (ORG) are soil components such as leaves, roots and woody pieces. All categories of aggregates were dried and weighed, determining their percentage contribution for the total weight of the soil sample obtained in the monolith.

\subsection{Organic carbon in soil macroaggregates}

Carbon analysis was carried out in triplicate to the category of biogenic macroaggregates, physical macroaggregates, root macroaggregates, and non-macroaggregate fraction identified in each monolith sampled under each cocoa agroforestry arrangement. The aggregates were previously crumbled and sieved through a $2 \mathrm{~mm}$ mesh to determine the organic carbon content by the organic matter oxidation method of Walkley \& Black (Zamudio et al., 2006).

\subsection{Statistical analysis and experimental design}

In each cocoa agroforestry system with an area of eight hectares, six homogeneous plots with $50 \mathrm{~m}$ between each other were selected. In each plot, a monolith was taken for macrofauna and aggregates. Thus, a completely random plot design with the factorial arrangement was used. 
Data were subjected to analysis of variance and comparison of means by the Fisher LSD test $(\mathrm{p}<0.05)$. With the data sets (macrofauna - aggregate morphology) a principal component analysis (PCA) was carried out to determine the similarity between agroforestry systems and to explore the relationship between variables of the same data set. Before the PCA of the macrofauna, data were transformed into $\log _{10}(x+1)$ to reduce the effect of dominant groups, and the separation of the agroforestry systems were tested with a Monte Carlo test. To determine the correlation between edaphic properties and aggregate morphology, a Pearson test was performed. Also, a co-inertia analysis was used to test co-variation between the data set (Dray et al., 2003), and the significance of the co-inertia value was tested with a Monte Carlo test. To facilitate interpretation in multivariate analyses, the macrofauna was grouped according to its ecological function. According to Brown et al. (2015), the edaphic fauna is divided into four functional groups: geophage/bioturbator, detritivore/decomposer, phytophagous/pest, and predator/parasite. The multivariate analyses were performed in the software R 3.4.4 (R Core Team, 2018) using the statistical package Ade4.

\section{RESULTS AND DISCUSSION}

\subsection{Soil edaphic properties}

In general, the different land uses had differences in all physical and chemical variables (Table 2). The formation of the soil at textural level varied significantly between soil uses related to the presence of some types of aggregates (for example, in the pasture there was a greater amount of silt). Therefore, the greater the sand content, the lower the protection of the organic matter and consequently the lower the availability of food for the edaphic macrofauna. The analyzed soils are from extremely to very acid, with high aluminum saturation and low cation exchange capacity. The total bases, calcium, magnesium and base saturation are also low. Natural fertility is low, similar to those described by the IGAC (2014). The content of bases (K, Mg, Na) was contrasted between the forest with other land uses, which probably could have an impact on the presence of some type of aggregates since it plays an important role in the aggregation and cementation of particles and in the formation of the soil structure.

Table 2. Characterization of edaphic properties of the different agroforestry systems associated with cocoa and the reference coverages (Forest and Pasture).

\begin{tabular}{|c|c|c|c|c|c|c|c|c|}
\hline Variable & Unit & Forest & AFS1 & AFS2 & AFS3 & AFS4 & AFS5 & Pasture \\
\hline Clay & $\%$ & $29.1 \pm 1.1^{b}$ & $39.9 \pm 3.6^{a}$ & $34.3 \pm 2.5^{b}$ & $27.4 \pm 1.5^{\mathrm{b}}$ & $39.8 \pm 1.0^{\mathrm{a}}$ & $30.5 \pm 2.10^{b}$ & $33.2 \pm 1.5^{\mathrm{b}}$ \\
\hline Sand & $\%$ & $55.9 \pm 2.9^{\mathrm{a}}$ & $41.1 \pm 3.2^{b}$ & $55.2 \pm 2.3^{\mathrm{a}}$ & $55.8 \pm 1.8^{\mathrm{a}}$ & $41.3 \pm 1.5^{\mathrm{b}}$ & $58.8 \pm 3.80^{\mathrm{a}}$ & $41.9 \pm 2.1^{\mathrm{b}}$ \\
\hline Silt & $\%$ & $14.9 \pm 2.1^{\mathrm{b}}$ & $18.9 \pm 2.5^{\mathrm{b}}$ & $10.5 \pm 1.6^{c}$ & $16.9 \pm 0.7^{b}$ & $18.9 \pm 1.0^{\mathrm{b}}$ & $10.6 \pm 2.50^{c}$ & $24.9 \pm 1.2^{\mathrm{a}}$ \\
\hline $\mathrm{BD}$ & $\mathrm{g} / \mathrm{cm} 3$ & $1.3 \pm 0.1^{\mathrm{a}}$ & $1.3 \pm 0.1^{\mathrm{b}}$ & $1.2 \pm 0.1^{c}$ & $1.2 \pm 0.1^{c}$ & $1.2 \pm 0.1^{c}$ & $1.3 \pm 0.10^{c}$ & $1.4 \pm 0.1^{\mathrm{a}}$ \\
\hline PD & $\mathrm{g} / \mathrm{cm} 3$ & $2.5 \pm 0.1^{\mathrm{a}}$ & $2.4 \pm 0.1^{\mathrm{b}}$ & $2.4 \pm 0.1^{\mathrm{b}}$ & $2.4 \pm 0.1^{\mathrm{b}}$ & $2.4 \pm 0.1^{\mathrm{b}}$ & $2.4 \pm 0.10^{\mathrm{b}}$ & $2.4 \pm 0.1^{\mathrm{b}}$ \\
\hline SM & $\%$ & $31.4 \pm 1.4^{c}$ & $33.5 \pm 0.7^{c}$ & $38.6 \pm 1.0^{b}$ & $30.9 \pm 0.9^{c}$ & $41.5 \pm 0.8^{\mathrm{a}}$ & $36.5 \pm 1.10^{b}$ & $25.5 \pm 0.6^{c}$ \\
\hline $\mathrm{TP}$ & $\%$ & $45.4 \pm 0.7^{\mathrm{b}}$ & $45.5 \pm 0.6^{\mathrm{b}}$ & $50.1 \pm 1.0^{\mathrm{b}}$ & $49.5 \pm 1.1^{\mathrm{a}}$ & $51.0 \pm 1.0^{\mathrm{a}}$ & $47.0 \pm 0.70^{\mathrm{b}}$ & $43.1 \pm 0.9^{\circ}$ \\
\hline PR & Mpa & $1.9 \pm 0.1^{b}$ & $1.7 \pm 0.1^{\mathrm{c}}$ & $1.7 \pm 0.1^{\mathrm{a}}$ & $1.2 \pm 0.1^{\mathrm{d}}$ & $1.6 \pm 0.1^{c}$ & $2.2 \pm 0.10^{\mathrm{a}}$ & $1.7 \pm 0.1^{\mathrm{c}}$ \\
\hline $\mathrm{pH}$ & & $5.1 \pm 0.1^{\mathrm{a}}$ & $4.7 \pm 0.1^{\mathrm{c}}$ & $4.9 \pm 0.1^{\mathrm{b}}$ & $5.0 \pm 0.1^{\mathrm{b}}$ & $4.6 \pm 0.1^{\mathrm{c}}$ & $5.1 \pm 0.1^{\mathrm{b}}$ & $4.8 \pm 0.1^{b}$ \\
\hline $\mathrm{OC}$ & $\%$ & $1.3 \pm 0.2^{\mathrm{a}}$ & $1.7 \pm 0.1^{\mathrm{a}}$ & $1.6 \pm 0.1^{\mathrm{a}}$ & $1.5 \pm 0.2^{\mathrm{a}}$ & $1.3 \pm 0.1^{\mathrm{a}}$ & $1.7 \pm 0.1^{\mathrm{a}}$ & $1.1 \pm 0.2^{b}$ \\
\hline $\mathrm{OM}$ & $\%$ & $2.6 \pm 0.4^{\mathrm{a}}$ & $2.9 \pm 0.1^{\mathrm{a}}$ & $2.7 \pm 0.3^{\mathrm{a}}$ & $2.6 \pm 0.4^{\mathrm{a}}$ & $2.3 \pm 0.1^{\mathrm{a}}$ & $2.9 \pm 0.1^{\mathrm{a}}$ & $1.8 \pm 0.3^{b}$ \\
\hline $\mathrm{N}$ & $\%$ & $0.1 \pm 0.1^{\mathrm{a}}$ & $0.2 \pm 0.1^{\mathrm{a}}$ & $0.1 \pm 0.1^{\mathrm{a}}$ & $0.1 \pm 0.1^{\mathrm{a}}$ & $0.1 \pm 0.1^{\mathrm{a}}$ & $0.1 \pm 0.1^{\mathrm{a}}$ & $0.1 \pm 0.1^{b}$ \\
\hline EA & $\mathrm{meq} / 100 \mathrm{~g}$ & $1.3 \pm 0.1^{\mathrm{d}}$ & $4.8 \pm 0.1^{\mathrm{b}}$ & $3.0 \pm 0.4^{\mathrm{c}}$ & $4.6 \pm 0.4^{\mathrm{b}}$ & $5.8 \pm 0.1^{\mathrm{a}}$ & $2.7 \pm 0.1^{\mathrm{c}}$ & $6.4 \pm 0.1^{\mathrm{a}}$ \\
\hline $\mathrm{Al}$ & $\mathrm{cmol}(-) / \mathrm{kg}$ & $0.3 \pm 0.1^{\mathrm{d}}$ & $2.7 \pm 0.1^{b}$ & $1.8 \pm 0.3^{\mathrm{c}}$ & $3.1 \pm 0.2^{\mathrm{b}}$ & $3.1 \pm 0.1^{\mathrm{b}}$ & $1.4 \pm 0.1^{\mathrm{c}}$ & $4.5 \pm 0.1^{\mathrm{a}}$ \\
\hline CEC & $\mathrm{cmol}(-) / \mathrm{kg}$ & $16.8 \pm 2.7^{c}$ & $22.3 \pm 2.1^{\mathrm{b}}$ & $22.8 \pm 2.0^{\mathrm{b}}$ & $25.7 \pm 2.2^{\mathrm{b}}$ & $31.9 \pm 0.8^{\mathrm{a}}$ & $27.2 \pm 2.4^{\mathrm{b}}$ & $27.2 \pm 1.1^{\mathrm{b}}$ \\
\hline $\mathrm{P}$ & $\mathrm{mg} / \mathrm{kg}$ & $6.6 \pm 0.5^{b}$ & $7.6 \pm 0.8^{\mathrm{b}}$ & $7.0 \pm 0.6$ & $7.4 \pm 1.9^{\mathrm{b}}$ & $4.6 \pm 0.3^{c}$ & $10.9 \pm 0.5^{\mathrm{a}}$ & $9.7 \pm 0.2^{\mathrm{a}}$ \\
\hline $\mathrm{Ca}$ & $\mathrm{meq} / 100 \mathrm{~g}$ & $1.5 \pm 0.2$ & $1.1 \pm 0.2$ & $1.3 \pm 0.5$ & $1.4 \pm 0.2$ & $0.9 \pm 0.1$ & $1.1 \pm 0.1$ & $1.2 \pm 0.1$ \\
\hline K & meq/100g & $0.1 \pm 0.1^{\mathrm{b}}$ & $0.2 \pm 0.1^{\mathrm{b}}$ & $0.1 \pm 0.1^{\mathrm{b}}$ & $0.2 \pm 0.1^{\mathrm{b}}$ & $0.3 \pm 0.1^{\mathrm{a}}$ & $0.2 \pm 0.1^{\mathrm{b}}$ & $0.3 \pm 0.1^{\mathrm{a}}$ \\
\hline $\mathrm{Mg}$ & meq/100g & $0.8 \pm 0.1^{\mathrm{b}}$ & $0.8 \pm 0.1^{\mathrm{b}}$ & $0.5 \pm 0.1^{\mathrm{c}}$ & $1.0 \pm 0.1^{\mathrm{a}}$ & $0.5 \pm 0.1^{c}$ & $0.7 \pm 0.1^{\mathrm{b}}$ & $0.8 \pm 0.1^{b}$ \\
\hline $\mathrm{Na}$ & meq/100g & $0.1 \pm 0.1^{\mathrm{b}}$ & $0.6 \pm 0.2^{\mathrm{a}}$ & $0.1 \pm 0.1^{\mathrm{b}}$ & $0.7 \pm 0.1^{\mathrm{a}}$ & $0.1 \pm 0.1^{\mathrm{b}}$ & $0.3 \pm 0.1^{\mathrm{b}}$ & $0.2 \pm 0.1^{b}$ \\
\hline
\end{tabular}

Mean: 6 replicas \pm standard error. $\mathrm{BD}=$ bulk density; $\mathrm{PD}=$ particle density; $\mathrm{SM}=$ soil moisture; $\mathrm{TP}=$ total porosity; $\mathrm{PR}=$ penetration resistance; $\mathrm{pH}=$ acidity coefficient; $\mathrm{OC}=$ organic carbon; $\mathrm{OM}=$ organic matter; $\mathrm{N}=$ total nitrogen; $\mathrm{EA}=$ exchangeable acidity; $\mathrm{Al}=$ aluminum $\mathrm{CEC}=$ cation exchange capacity; $\mathrm{P}=$ available phosphorus; $\mathrm{Ca}=$ calcium; $\mathrm{K}=$ potassium; $\mathrm{Mg}=$ magnesium; $\mathrm{Na}=$ Sodium. Mean values followed by the same letter within rows do not differ significantly according to the LSD Fisher test $(\mathrm{p}<0.05)$. 


\subsection{Soil macrofauna}

On average, $2739 \pm 313.3$ individuals $\mathrm{m}^{-2}$ and $7 \pm 0.4$ taxa were recorded per soil sample under the agroforestry systems associated with cocoa (Table 3). The forest reference coverage represented the greatest richness of macrofauna groups due to favorable conditions (environmental, such as temperature and humidity, and soil conditions, such as chemical and physical variables) for the presence of different functional groups (Table 3). Regarding the functional groups of macrofauna, the geophage/bioturbator group had $90 \%$ of the total density observed since they ingest and feed mainly on the organic matter of the soil at different levels of humification and/or dead roots; soil conditions that were favorable in different cacao agroforestry systems and the forest (Table 3). When determining the effect of land uses, the PCA explained $44 \%$ of the total variance and is highly significant according to the Monte Carlo test ( $\mathrm{p}<0.001$, Figure 1), relating some agroforestry systems to the forest and the forest separated from the pasture. Due to the presence of the different functional groups of macrofauna (Figure 1) by the arrangement and composition in the agroforestry systems AFS2 and AFS1, greater contribution of biomass was allowed, similar to the Forest.

\subsection{Macroaggregates formation}

The proportion and type of macroaggregates were influenced by the land uses, predominating non-macroaggregated fraction in most sites (Table 4). This behavior is supported by the theory of aggregate hierarchy (Oades, 1984), which states that the microaggregates are first formed freely and then serve as the building blocks for the formation of macroaggregates. However, the macroaggregates return to microaggregates because they are joined by temporary agents (Six et al., 2004), and the macroaggregates are more sensitive to changes in soil management and environmental changes

Table 3. Density of macrofauna (individuals $\mathrm{m}^{-2}$ ) present in the different agroforestry systems associated with cocoa and the reference coverages (Forest and Pasture).

\begin{tabular}{|c|c|c|c|c|c|c|c|}
\hline $\begin{array}{c}\text { Functional } \\
\text { Group }\end{array}$ & Forest & AFS1 & AFS2 & AFS3 & AFS4 & AFS5 & Pasture \\
\hline \multicolumn{8}{|c|}{ Geophage/Bioturbator } \\
\hline Hymenoptera & $693.3 \pm 197^{a}$ & $157.3 \pm 90^{\mathrm{b}}$ & $106.7 \pm 53^{b}$ & $184 \pm 106^{\mathrm{b}}$ & $42.7 \pm 22^{\mathrm{b}}$ & $93.3 \pm 27^{b}$ & $258.7 \pm 104^{\mathrm{b}}$ \\
\hline Isoptera & $2237.3 \pm 514$ & $2701.3 \pm 815$ & $3133.3 \pm 1020$ & $2149.3 \pm 939$ & $2080 \pm 1118$ & $1826.7 \pm 522$ & - \\
\hline Oligochaeta & $85.3 \pm 17^{c}$ & $261.3 \pm 54^{\mathrm{b}}$ & $157.3 \pm 49^{\mathrm{bc}}$ & $170.7 \pm 28^{\mathrm{bc}}$ & $90.7 \pm 41^{c}$ & $488 \pm 105^{\mathrm{a}}$ & $450.7 \pm 71^{\mathrm{a}}$ \\
\hline \multicolumn{8}{|c|}{ Detritivore/Decomposer } \\
\hline Blattodea & $34.7 \pm 19^{\mathrm{a}}$ & $2.7 \pm 3^{a}$ & $16 \pm 10^{a}$ & - & - & - & $8 \pm 5^{a}$ \\
\hline Coleoptera & $98.7 \pm 3^{\mathrm{a}}$ & $21.3 \pm 8^{\mathrm{b}}$ & $53.3 \pm 23^{\mathrm{ab}}$ & $18.7 \pm 10^{\mathrm{b}}$ & $18.7 \pm 8^{\mathrm{b}}$ & $29.3 \pm 11^{\mathrm{b}}$ & $104 \pm 27^{a}$ \\
\hline Collembola & $56 \pm 21^{\mathrm{a}}$ & $5.3 \pm 5^{\mathrm{b}}$ & $2.7 \pm 3^{\mathrm{b}}$ & $5.3 \pm 3^{\mathrm{b}}$ & $5.3 \pm 5^{b}$ & - & - \\
\hline Diplura & $58.7 \pm 24^{\mathrm{a}}$ & - & - & - & - & - & - \\
\hline Diplopoda & $144 \pm 22^{\mathrm{a}}$ & $16 \pm 13^{c}$ & $8 \pm 4^{c}$ & $8 \pm 5^{c}$ & $5.3 \pm 5^{c}$ & $56 \pm 18^{\mathrm{b}}$ & - \\
\hline Isopoda & $93.3 \pm 21^{\mathrm{ab}}$ & $53.3 \pm 23^{\mathrm{bc}}$ & $138.7 \pm 51^{\mathrm{a}}$ & $5.3 \pm 3^{c}$ & $10.7 \pm 5^{c}$ & $40 \pm 21^{\mathrm{bc}}$ & $5.30 \pm 5 c$ \\
\hline Symphyla & $13.3 \pm 10$ & $18.7 \pm 10$ & $24 \pm 12$ & $5.3 \pm 5$ & $2.7 \pm 3$ & $16 \pm 6$ & $50.70 \pm 26$ \\
\hline \multicolumn{8}{|l|}{ Phytophagous/Plague } \\
\hline Gastropoda & $2.7 \pm 3^{b}$ & $2.7 \pm 3^{b}$ & $18.7 \pm 10^{\mathrm{a}}$ & $2.7 \pm 3^{\mathrm{b}}$ & - & - & - \\
\hline Hemiptera & $18.7 \pm 5^{\mathrm{a}}$ & $2.7 \pm 3^{b}$ & $13.3 \pm 8^{\mathrm{ab}}$ & $2.7 \pm 3^{b}$ & $2.7 \pm 3^{\mathrm{b}}$ & - & $2.70 \pm 3^{b}$ \\
\hline L. Lepidoptera & - & - & - & $2.7 \pm 3$ & $2.7 \pm 3$ & $2.7 \pm 3$ & - \\
\hline \multicolumn{8}{|l|}{ Predator/Parasite } \\
\hline Araneae & $165.3 \pm 24^{\mathrm{a}}$ & $34.7 \pm 16^{\mathrm{b}}$ & $24 \pm 4^{\mathrm{b}}$ & $8 \pm 5^{b}$ & $26.7 \pm 11^{\mathrm{b}}$ & $13.3 \pm 6^{\mathrm{b}}$ & $16.00 \pm 6^{\mathrm{b}}$ \\
\hline Chilopoda & $56 \pm 5^{\mathrm{a}}$ & - & $29.3 \pm 15^{\mathrm{b}}$ & $5.3 \pm 3^{c}$ & $2.7 \pm 3^{c}$ & - & - \\
\hline Mantodea & - & $2.7 \pm 3$ & - & - & - & - & - \\
\hline Nematodo & - & $5.3 \pm 5$ & $24 \pm 13$ & - & $5.3 \pm 3$ & $5.3 \pm 5$ & - \\
\hline Pseudoscorpionida & $50.7 \pm 16^{a}$ & - & - & - & - & - & - \\
\hline Total density & $3808 \pm 604$ & $3285 \pm 797$ & $3749 \pm 1007$ & $2568 \pm 933$ & $2296 \pm 1121$ & $2570 \pm 513$ & $896 \pm 95$ \\
\hline Richness & $12.8 \pm 0.5^{\mathrm{a}}$ & $7 \pm 0.9^{c}$ & $9.6 \pm 1^{\mathrm{b}}$ & $6 \pm 0.4^{\mathrm{cd}}$ & $5.6 \pm 0.6^{\mathrm{cd}}$ & $6.8 \pm 0.4^{\text {cd }}$ & $5.1 \pm 1^{\mathrm{d}}$ \\
\hline
\end{tabular}

Mean: 6 replicas \pm standard error. Mean values followed by the same letter within rows do not differ significantly according to the LSD Fisher test $(\mathrm{p}<0.05)$. 


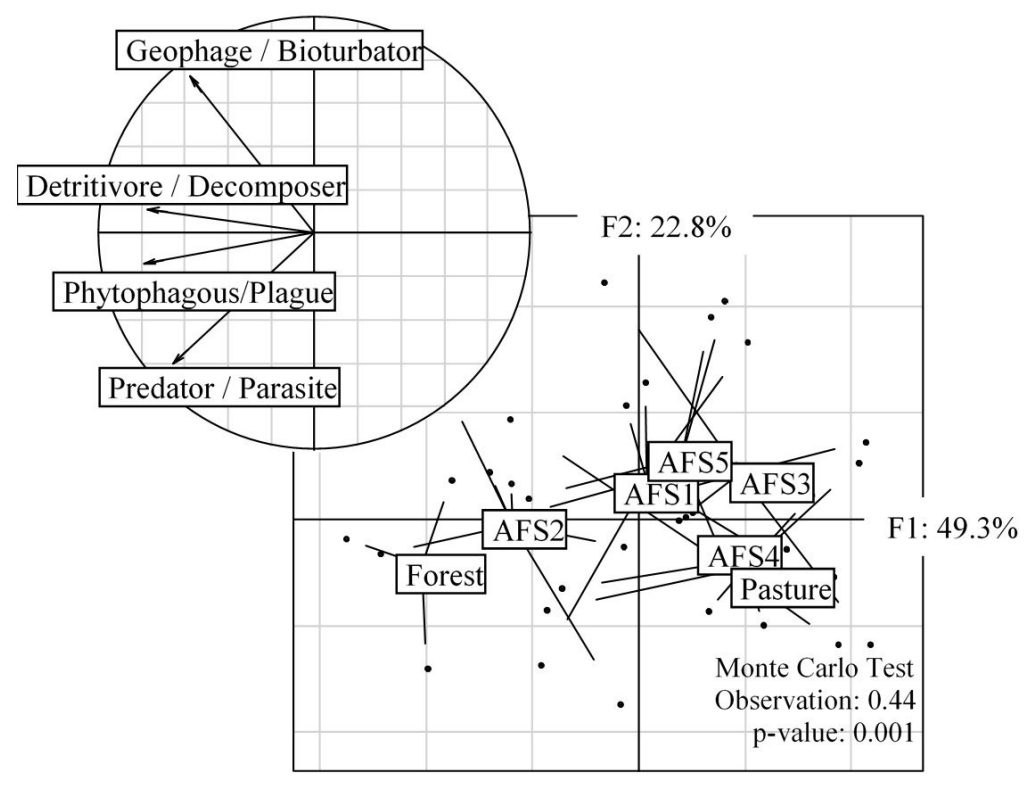

Figure 1. Projection in the factorial plane F1/F2 of principal component analysis of the variables (functional groups of macrofauna) and of the sampling points grouped according to the different agroforestry systems associated with cocoa and the reference coverages (Forest and Pasture).

Table 4. Proportion of macroaggregates of the soil present in the different agroforestry systems associated with cocoa and the reference coverages (Forest and Pasture).

\begin{tabular}{|ccccc|}
\hline Land uses & Bio $_{\text {Macro }}$ & Phys $_{\text {Macro }}$ & Root $_{\text {Macro }}$ & Non $_{\text {Macro }}$ \\
\hline Forest & $16.0 \pm 4.0^{\mathrm{bB}}$ & $18.7 \pm 2.9^{\mathrm{bcdB}}$ & $12.5 \pm 2.8^{\mathrm{bB}}$ & $52.3 \pm 5.4^{\mathrm{abA}}$ \\
\hline AFS1 & $41.7 \pm 4.9^{\mathrm{aA}}$ & $21.4 \pm 4.7^{\mathrm{bcdB}}$ & $2.8 \pm 1.1^{\mathrm{cC}}$ & $34.0 \pm 5.5^{\mathrm{cdeA}}$ \\
\hline AFS2 & $38.8 \pm 5.6^{\mathrm{aA}}$ & $9.9 \pm 1.3^{\mathrm{dB}}$ & $6.6 \pm 1.6^{\mathrm{bcBC}}$ & $44.3 \pm 4.2^{\mathrm{bcA}}$ \\
\hline AFS3 & $43.1 \pm 6.9^{\mathrm{aA}}$ & $22.6 \pm 5.1^{\mathrm{bcB}}$ & $3.6 \pm 1.6^{\mathrm{cC}}$ & $30.5 \pm 4.8^{\mathrm{deAB}}$ \\
\hline AFS4 & $24.3 \pm 3.2^{\mathrm{bB}}$ & $31.0 \pm 6.0^{\mathrm{abAB}}$ & $8.5 \pm 2.5^{\mathrm{bcC}}$ & $36.1 \pm 3.8^{\mathrm{cdA}}$ \\
\hline AFS5 & $20.3 \pm 2.9^{\mathrm{bB}}$ & $14.5 \pm 2.8^{\mathrm{cdBC}}$ & $7.3 \pm 1.2^{\mathrm{bcCD}}$ & $57.8 \pm 5.5^{\mathrm{aA}}$ \\
\hline Pasture & $12.3 \pm 2.1^{\mathrm{bC}}$ & $40.6 \pm 5.7^{\mathrm{aA}}$ & $25.5 \pm 3.4^{\mathrm{aB}}$ & $21.5 \pm 2.1^{\mathrm{eBC}}$ \\
\hline Mean & $28.1 \pm 2.4^{\mathrm{B}}$ & $22.7 \pm 2.1^{\mathrm{C}}$ & $9.6 \pm 1.4^{\mathrm{D}}$ & $39.5 \pm 2.4^{\mathrm{A}}$ \\
\hline
\end{tabular}

Mean: 6 replicas \pm standard error. Mean values followed by the same capital letter in rows and the same lowercase letter in columns

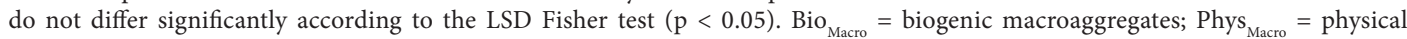
macroaggregates; Root $_{\text {Macro }}=$ Root macroaggregates; Non $_{\text {Macro }}=$ non-macroaggregated fraction .

(Chen et al., 2017; Zhong et al., 2017). Loss et al. (2014) and Pulleman et al. (2005) mentioned that the dynamics of soil aggregation, including the formation of macroaggregates by biogenic and physical processes, are affected by soil management, a situation presented in this study when moving from pasture management to agroforestry systems with cocoa. In this sense, the use of pasture soil presented the highest contents of root macroaggregates. According to Solly et al. (2014), the pastures have higher biomass of fine roots and rotation of roots in comparison with forest soils, being determinants in the macroaggregation due to the increase in density and root length (Batista et al., 2013; Erktan et al., 2016).

The axes 1 and 2 in the PCA explained $72.5 \%$ of the variability of the data for the aggregate morphology. Axis 1 compared land uses with a higher proportion of non-macroaggregated fraction (associated with forest and AFS5) of those with a greater proportion of physical macroaggregates (associated with pasture and AFS4), separating land uses from lower to higher intensification. Axis 2 clearly separated the biogenic macroaggregates (associated with AFS1, AFS2, and AFS3) from the root macroaggregates (pasture), contrasting 
the land uses in accordance to the contribution of biomass and microclimatic regulation within the structures agroforestry. The effect of land uses on the proportion of macroaggregates is highly significant $(\mathrm{p}<0.001)$ and explained $55 \%$ of the total variance of the data according to the Monte Carlo test (Figure 2). The results suggest that the presence of trees and litter in the soil are determinant factors that favor the activity of the macrofauna (Moura et al., 2015), allowing them to act on the soil generating biogenic structures by mixing the mineral soil with organic matters (Blouin et al., 2013).

\subsection{Relationship and covariation between the formation of aggregates and edaphic properties}

Edaphic properties were found to affect the presence of some types of soil macroaggregates $(\mathrm{p}<0.05)$. In this sense, the aggregation depended on intrinsic properties such as texture, which correlated positively with the presence of physical macroaggregates and the silt content (Table 5). However, in the non-macroaggregated fraction type, the silt content correlated negatively.
Thus, a negative correlation was found between the sand content and the physical macroaggregate (Table 5). Six et al. (2004) reported that the highest presence of iron and aluminum oxides occurs in soil with a higher silt content, which allows the aggregation of some categories as physical macroaggregates.

The hardness of the soil depending on the texture and availability of water in the soil correlated with different physical properties was observed (BD, SM, TP, PR), affecting negatively the presence of biogenic, physical and root macroaggregate. However, in the case of the macroaggregates of the root and the non-macroaggregated fraction, they showed a positive correlation with BD, SM, and PR (Table 5). At the level of chemical properties, the $\mathrm{P}$ content had a negative impact on the formation of macroaggregates of biogenic type, opposite to the $\mathrm{Na}$, which benefits their formation. At the level of root and physical macroaggregates, $\mathrm{K}$ benefits their formation.

Inverse relationships were observed between some edaphic properties and between the types of aggregates such as the non-macroaggregated fraction and physical macroaggregates (Table 5). Probably the physical one depends on a first state (non-macroaggregated

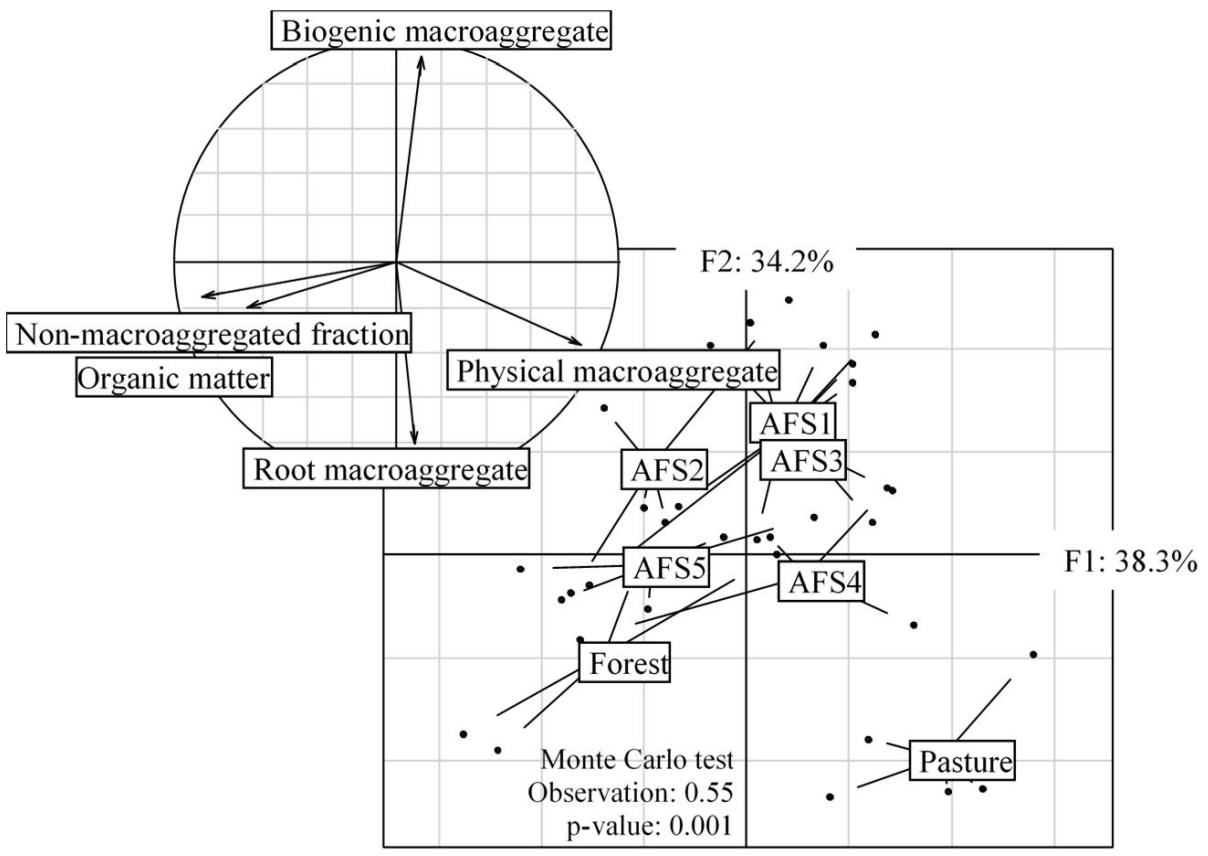

Figure 2. Projection in the factorial plane F1/F2 of a principal component analysis of the variables (aggregate morphology) and of the sampling points grouped according to the different agroforestry systems associated with cocoa and the reference coverages (Forest and Pasture). 
Table 5. Pearson's coefficients ( $\mathrm{r}$ ) between edaphic properties and macroaggregate types.

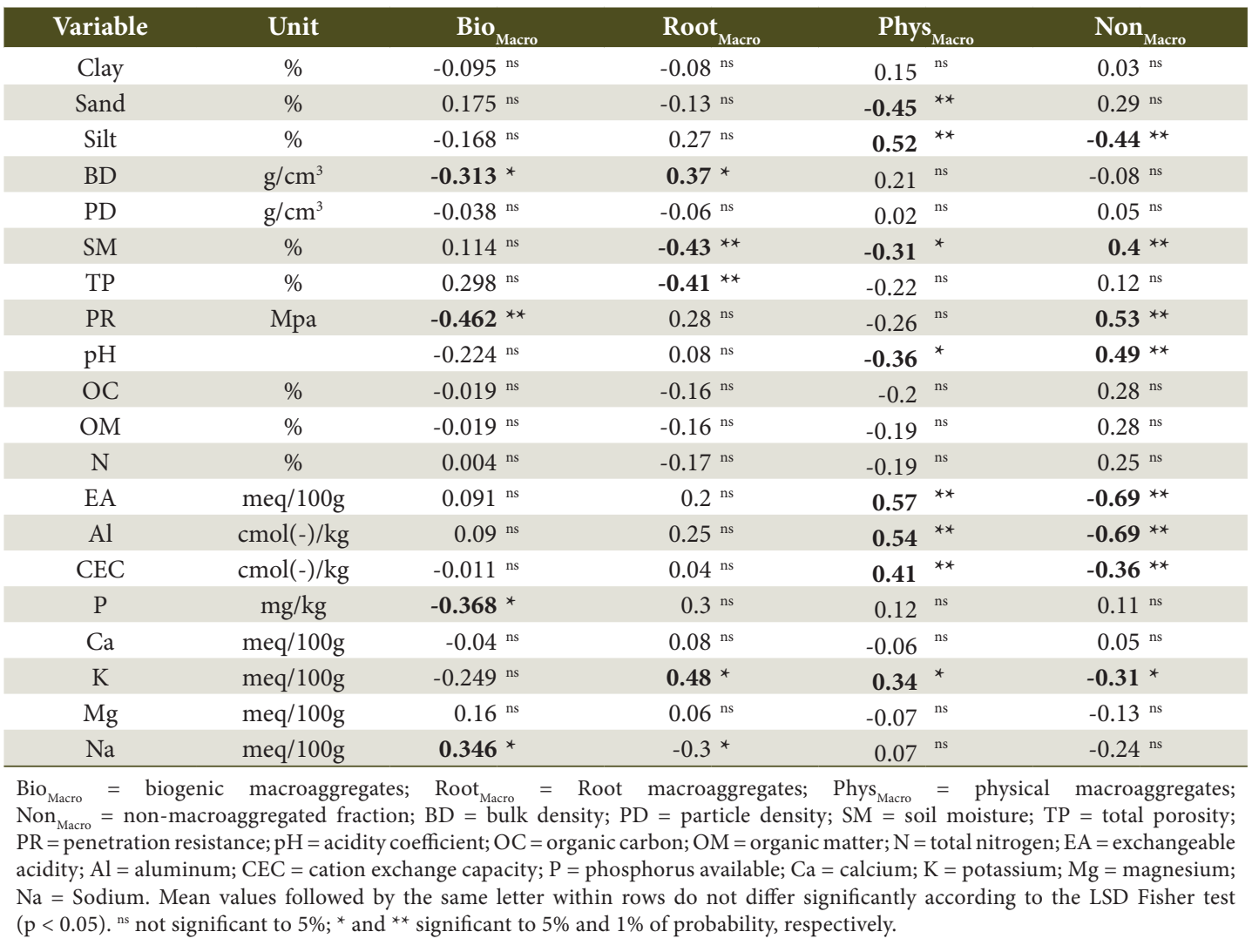

fraction) as some intrinsic variables of the soil for their respective formation, supported by the inverse correlations between this category of aggregates in edaphic properties such as the content of silts, SM, $\mathrm{pH}, \mathrm{EA}, \mathrm{Al}, \mathrm{CEC}$ and $\mathrm{K}$ (Table 5). In different studies (Loss et al., 2014; Batista et al., 2013; Pulleman et al., 2005) the relationship between biogenic macroaggregates and elements contents in the soil has been observed, such as $\mathrm{Ca}$, working as a cementing agent, situation not presented in this study (Table 5). However, in the case of $\mathrm{Na}$, there was a relationship $(\mathrm{r}=0.34 ; \mathrm{p}$-value $<0.05)$ with biogenic macroaggregates.

Regarding the covariation between macroaggregates and soil edaphic properties (Figure 3), the co-inertia analysis indicated that it was significant (RV: 0.37, p-value: 0.001, Monte Carlo test), showing a high dependence on the formation of aggregates to intrinsic properties of the soil. Lavelle et al. (2014) report the opposite. The authors found a certain level of independence to any positive or negative effect between the chemical and physical properties of the soil for the formation of the aggregates.

\subsection{Covariation between macrofauna and macroaggregates}

The co-inertia analysis showed a significant covariation (RV: 0.22, p-value: 0.001, Monte Carlo test) between functional groups of macrofauna and aggregate morphology (Figure 4). For example, the geophage/bioturbator group was positively associated with biogenic macroaggregates, verifying the ability of these individuals (earthworms, ants and termites) to influence the soil (Jouquet et al., 2016; Lavelle et al., 2016).

In this sense, biogenic macroaggregates increased a lot, taking the use of pasture soil as a reference compared to the different agroforestry systems associated with cocoa (Table 4). Velásquez et al. $(2007,2012)$ found an increase of $28.3 \%$ in the accumulation of biogenic aggregates produced by the main engineers of the soil ecosystem (Isoptera and Oligochaeta). In the areas of agroforestry systems with cocoa, there is a strong relationship with the number of aggregates of biogenic origin due to the contribution of constant 


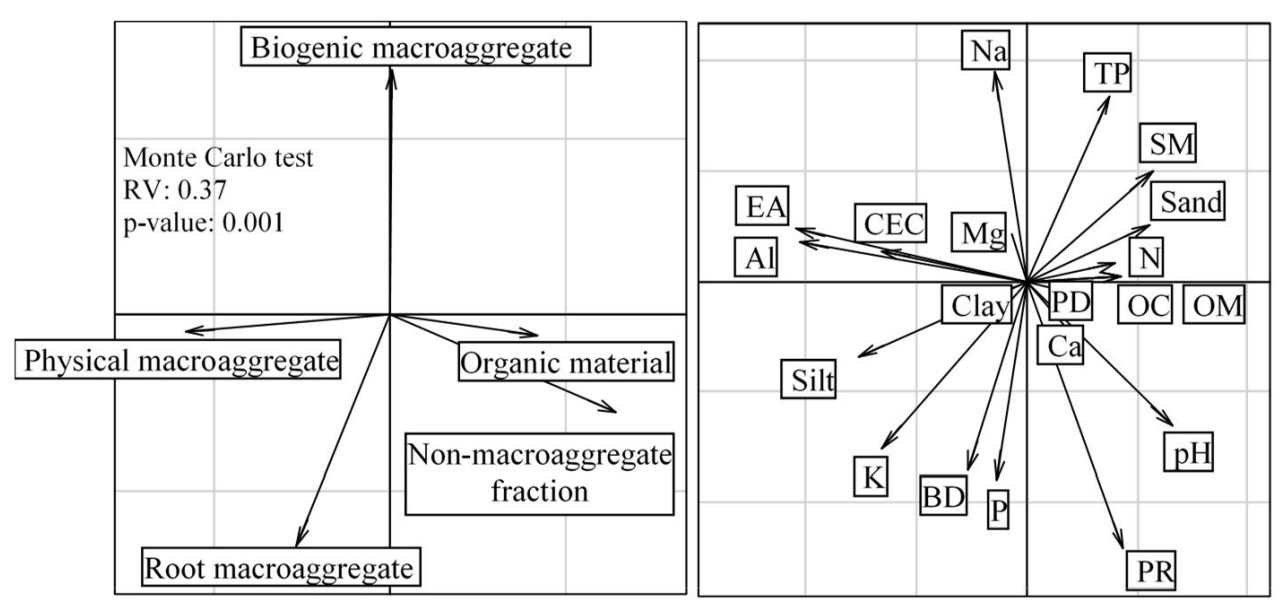

Figure 3. Projection in the factorial plane F1/F2 of a co-inertia analysis of the variables morphology of aggregates (left) and soil edaphic properties (right) measured in agroforestry systems associated with cocoa and the reference coverages (forest and pasture). See abbreviation in Table 2.
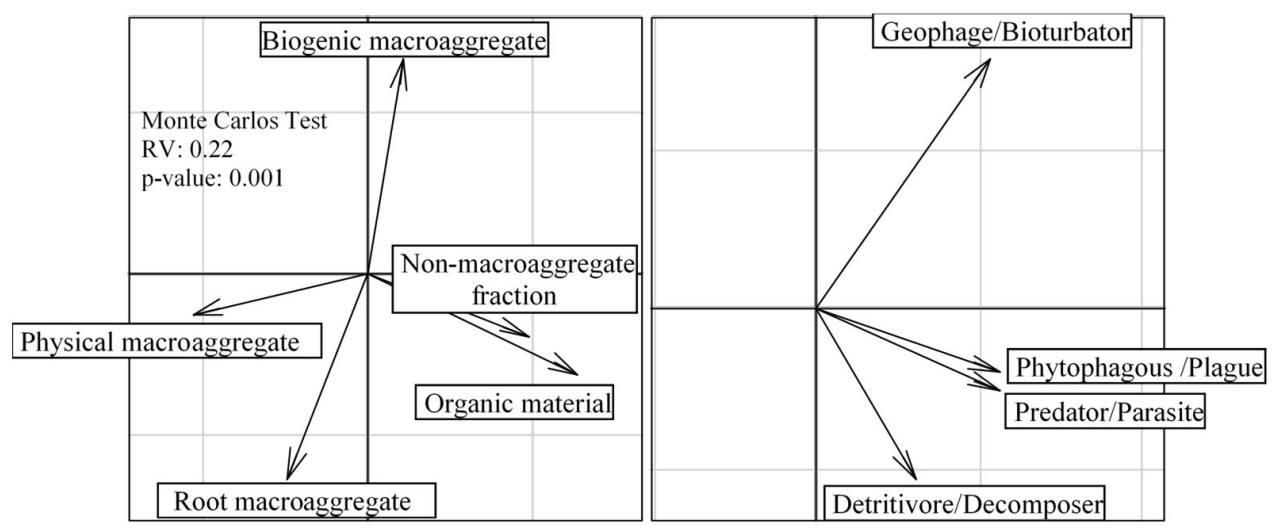

Figure 4. Projection in the factorial plane F1/F2 of a co-inertia analysis of the morphology variables of aggregates (left) and functional groups of macrofauna (right) measured in agroforestry systems associated with cocoa and the reference coverages (forest and pasture).

litter, source of food for individuals of the edaphic macrofauna such as Oligochaeta (Batista et al., 2013). According to Jongmans et al. (2003), the Oligochaeta are important engineers of the ecosystem and act in the formation of aggregates rich in organic matter. Also, the predatory group was related to the organic matter category due to its preference for sites that offer favorable microclimatic conditions (Moço et al., 2010).

\subsection{Organic carbon in macroaggregates}

The organic carbon (OC) content in the macroaggregates was different $(\mathrm{p}<0.05)$ for each soil use (Table 6). By aggregate, the OC was different $(p<0.05)$ between land uses (Table 6). On average, the root macroaggregates and the non-macroaggregated fraction have the greatest capacity to store carbon (Table 6). Thus, roots are an important part of the OC balance. According to Nair et al. (2009), more than a third of OC assimilated by the plant is deposited to the soil by root rotation and root exudates, while the non-macroaggregated fraction has been demonstrated to effectively protect carbon from degradation (Zhang et al., 2013; Zhong et al., 2017).

For soil use, the results highlight some cocoa agroforestry systems (AFS1, AFS3, AFS4, and AFS5) because they present remarkable carbon contents within their biogenic macroaggregates (Table 6). These values possibly reflect an incidence of the amount 
Table 6. Organic carbon content (\%) in each type of macroaggregate present in the different agroforestry systems associated with cocoa and the reference coverages (Forest and Pasture).

\begin{tabular}{lcccc}
\multicolumn{1}{c}{ Land uses } & Bio $_{\text {Macro }}$ & Phys $_{\text {Macro }}$ & Root $_{\text {Macro }}$ & Non $_{\text {Macro }}$ \\
\hline Forest & $2.7 \pm 0.1^{\mathrm{cB}}$ & $2.0 \pm 0.1^{\mathrm{abC}}$ & $2.9 \pm 0.2^{\mathrm{bcdAB}}$ & $3.22 \pm 0.1^{\mathrm{abA}}$ \\
\hline AFS1 & $2.8 \pm 0.1^{\mathrm{bcA}}$ & $1.0 \pm 0.1^{\mathrm{dB}}$ & $2.8 \pm 0.2^{\mathrm{cdA}}$ & $2.57 \pm 0.1^{\mathrm{dA}}$ \\
\hline AFS2 & $2.3 \pm 0.1^{\mathrm{dBC}}$ & $2.1 \pm 0.1^{\mathrm{bcC}}$ & $2.6 \pm 0.2^{\mathrm{dAB}}$ & $2.83 \pm 0.1^{\mathrm{cdA}}$ \\
\hline AFS3 & $3.4 \pm 0.1^{\mathrm{aA}}$ & $2.1 \pm 0.1^{\mathrm{abcB}}$ & $3.3 \pm 0.2^{\mathrm{abcA}}$ & $3.33 \pm 0.1^{\mathrm{aA}}$ \\
AFS4 & $3.3 \pm 0.2^{\mathrm{aAB}}$ & $1.9 \pm 0.1^{\mathrm{cdC}}$ & $3.6 \pm 0.1^{\mathrm{aA}}$ & $3.15 \pm 0.2^{\mathrm{abB}}$ \\
AFS5 & $3.1 \pm 0.2^{\mathrm{abA}}$ & $2.5 \pm 0.2^{\mathrm{aB}}$ & $3.4 \pm 0.1^{\mathrm{abA}}$ & $2.99 \pm 0.1^{\mathrm{bcA}}$ \\
Pasture & $2.6 \pm 0.1^{\mathrm{cB}}$ & $2.2 \pm 0.2^{\mathrm{abC}}$ & $3.1 \pm 0.1^{\mathrm{abcA}}$ & $2.83 \pm 0.1^{\mathrm{cdAB}}$ \\
\hline Mean & $2.89 \pm 0.06^{\mathrm{B}}$ & $2.09 \pm 0.05^{\mathrm{C}}$ & $3.1 \pm 0.07^{\mathrm{A}}$ & $2.99 \pm 0.05^{\mathrm{AB}}$ \\
\hline
\end{tabular}

Mean: 6 replicas \pm standard error. Mean values followed by the same capital letter in rows and the same lowercase letter in columns do not differ significantly according to the LSD Fisher test $(\mathrm{p}<0.05)$. Bio ${ }_{\text {Macro }}=$ biogenic macroaggregates; Phys ${ }_{\text {Macro }}=$ physical macroaggregates; Root $_{\text {Macro }}=$ Root macroaggregates; Non $_{\text {Macro }}=$ non-macroaggregated fraction .

and quality of vegetation residues available for soil biota (Nair et al., 2009; Monroe et al., 2016), which allowed incorporating more organic carbon to these macroaggregates. Also, these agroforestry cocoa systems (AFS1, AFS3, AFS4, and AFS5), being conservationist systems, increase carbon stabilization due to the greater formation and maintenance of biogenic aggregates (Brussaard et al., 2007).

When comparing the carbon content in some types of aggregates (biogenic macroaggregate and physical macroaggregate) and among land uses, it was found that the oxidation rate was favored under pasture coverage, resulting in lower levels of organic carbon (Table 6). A relationship was found between the organic carbon content in biogenic macroaggregates with their presence in different AFS (AFS3 and AFS5). This pattern may be due to the greater action of organic matter in that area, which may be acting as welding for macroaggregates. Normally, the organic matter retains more water causing the moistening and drying cycles to occur more slowly, giving more stability to the aggregates.

\section{CONCLUSIONS}

The cocoa agroforestry systems with a diversified shade canopy established from stubble (AFS1 and AFS2) had a positive effect when increasing the populations of geophage/bioturbator functional groups, as well as the biogenic macroaggregates.

The presence of trees and litter in the soil are determinant factors that favor the macrofauna's activity, allowing them to act on the soil generating biogenic structures when mixing the mineral soil with organic matters.

The organic carbon content was higher in biogenic aggregates when they came from cocoa agroforestry systems.

\section{SUBMISSION STATUS}

Received: 31 oct., 2017

Accepted: 24 nov., 2018

\section{CORRESPONDENCE TO}

\section{Leonardo Rodríguez Suárez}

Universidad de la Amazonia, Calle 17 Diagonal 17 con Carrera 3F, Barrio Porvenir, Florencia, ZIP code 180001-180009, Caquetá, Colombia e-mail: 1.rodriguezsuarez@outlook.com

\section{REFERENCES}

Acar M, Celik I, Günal H. Effects of long-term tillage systems on aggregate-associated organic carbon in the eastern Mediterranean region of Turkey. Eurasian Journal of Soil Science 2018; 7(1): 51-58. http://dx.doi. org/10.18393/ejss.335329.

Batista I, Correia MEF, Pereira MG, Bieluczyk W, Schiavo JA, Mello NA. Caracterização dos agregados em solos sob cultivo no Cerrado, MS. Semina: Ciências Agrárias 2013; 34(4). http://dx.doi.org/10.5433/1679-0359.2013v34n4p1535.

Blouin M, Hodson ME, Delgado EA, Baker G, Brussaard L, Butt KR et al. A review of earthworm impact on soil function and ecosystem services. European Journal of Soil Science 2013; 64(2): 161-182. http://dx.doi.org/10.1111/ ejss. 12025. 
Brown GG, Niva CC, Zagatto MRG, Ferreira S A, Nadolny HS, Cardoso GBX et al. Biodiversidade da fauna do solo e sua contribuição para os serviços ambientais. In: Parron LM, Garcia JR, Oliveira ED, Brown GG, Prado RB, editors. Serviços ambientais em sistemas agrícolas e florestais do Bioma Mata Atlântica. Brasília: Embrapa; 2015.

Brussaard L, Pulleman MM, Ouédraogo É, Mando A, Six J. Soil fauna and soil function in the fabric of the food web. Pedobiologia 2007; 50(6): 447-462. http://dx.doi. org/10.1016/j.pedobi.2006.10.007.

Chen C, Liu W, Jiang X, Wu J. Effects of rubber-based agroforestry systems on soil aggregation and associated soil organic carbon: implications for land use. Geoderma 2017; 299(1): 13-24. http://dx.doi.org/10.1016/j. geoderma.2017.03.021.

Dray S, Chessel D, Thioulouse J. Co-inertia analysis and the linking of ecological data tables. Ecology 2003; 84(11): 3078-3089. http://dx.doi.org/10.1890/03-0178.

Erktan A, Cécillon L, Graf F, Roumet C, Legout C, Rey F. Increase in soil aggregate stability along a Mediterranean successional gradient in severely eroded gully bed ecosystems: combined effects of soil, root traits and plant community characteristics. Plant and Soil 2016; 398(1-2): 121-137. http://dx.doi.org/10.1007/s11104-015-2647-6.

Instituto Geográfico Agustín Codazzi - IGAC. Estudio general de suelos y zonificación de tierras departamento de Caquetá, escala 1.100.000. Bogotá: Instituto Geográfico Agustín Codazzi; 2014. 410 p.

Jongmans AG, Pulleman MM, Balabane M, Van Oort F, Marinissen JC. Soil structure and characteristics of organic matter in two orchards differing in earthworm activity. Applied Soil Ecology 2003; 24(3): 219-232. http://dx.doi. org/10.1016/S0929-1393(03)00072-6.

Jouquet P, Bottinelli N, Shanbhag RR, Bourguignon T, Traoré S, Abbasi SA. Termites: the neglected soil engineers of tropical soils. Soil Science 2016; 181(3-4): 157-165. http://dx.doi.org/10.1097/SS.0000000000000119.

Lavelle P, Rodríguez N, Arguello O, Bernal J, Botero C, Chaparro $\mathrm{P}$ et al. Soil ecosystem services and land use in the rapidly changing Orinoco River Basin of Colombia. Agriculture, Ecosystems \& Environment 2014; 185: 106-117. http://dx.doi.org/10.1016/j.agee.2013.12.020.

Lavelle P, Spain A, Blouin M, Brown G, Decaëns T, Grimaldi $\mathrm{M}$ et al. Ecosystem engineers in a self-organized soil: a review of concepts and future research questions. Soil Science 2016; 181(3/4): 91-109. http://dx.doi.org/10.1097/ SS.0000000000000155.

Loss A, Pereira MG, Costa EM, Beutler SJ. Soil fertility, physical and chemical organic matter fractions, natural ${ }_{13} \mathrm{C}$ and ${ }_{15} \mathrm{~N}$ abundance in biogenic and physicogenic aggregates in areas under different land use systems. Soil Research 2014; 52(7): 685-697. http://dx.doi.org/10.1071/SR14045.
Lubbers IM, Pulleman MM, Van Groenigen JW. Can earthworms simultaneously enhance decomposition and stabilization of plant residue carbon? Soil Biology \& Biochemistry 2017; 105: 12-24. http://dx.doi.org/10.1016/j. soilbio.2016.11.008.

Moço MKS, Gama-Rodrigues EF, Gama-Rodrigues AC, Machado RC, Baligar VC. Relationships between invertebrate communities, litter quality and soil attributes under different cacao agroforestry systems in the south of Bahia, Brazil. Applied Soil Ecology 2010; 46(3): 347-354. http://dx.doi.org/10.1016/j.apsoil.2010.10.006.

Moço MKS, Gama-Rodrigues EF, Gama-Rodrigues AC, Machado RCR, Baligar VC. Soil and litter fauna of cacao agroforestry systems in Bahia, Brazil. Agroforestry Systems 2009; 76(1): 127-138. http://dx.doi.org/10.1007/ s10457-008-9178-6.

Monroe PHM, Gama-Rodrigues EF, Gama-Rodrigues AC, Marques JRB. Soil carbon stocks and origin under different cacao agroforestry systems in Southern Bahia, Brazil. Agriculture, Ecosystems \& Environment 2016; 221(1): 99-108. http://dx.doi.org/10.1016/j.agee.2016.01.022.

Moura EG, Aguiar ACF, Piedade AR, Rousseau GX. Contribution of legume tree residues and macrofauna to the improvement of abiotic soil properties in the eastern Amazon. Applied Soil Ecology 2015; 86: 91-99. http:// dx.doi.org/10.1016/j.apsoil.2014.10.008.

Nair PR, Nair VD, Kumar BM, Haile SG. Soil carbon sequestration in tropical agroforestry systems: a feasibility appraisal. Environmental Science \& Policy 2009; 12(8): 1099-1111. http://dx.doi.org/10.1016/j.envsci.2009.01.010.

Oades JM. Soil organic matter and structural stability: mechanisms and implications for management. Plant and Soil 1984; 76(1-3): 319-337. http://dx.doi.org/10.1007/ BF02205590.

Pulleman MM, Six J, Van Breemen N, Jongmans AG. Soil organic matter distribution and microaggregate characteristics as affected by agricultural management and earthworm activity. European Journal of Soil Science 2005; 56(4): 453-467. http://dx.doi.org/10.1111/j.13652389.2004.00696.x.

$\mathrm{R}$ Core Team. $\mathrm{R}$ : a language and environment for statistical computing [online]. Vienna: R Foundation for Statistical Computing; 2018 [cited 2017 Oct 31]. Available from: https://www.R-project.org/

Silva EC No, Gervasio M, Feitosa JC, Corrêa TA No. Aggregate formation and soil organic matter under different vegetation types in Atlantic Forest from Southeastern Brazil. Semina: Ciências Agrárias 2016; 37(6): 3927. http:// dx.doi.org/10.5433/1679-0359.2016v37n6p3927.

Six J, Bossuyt H, Degryze S, Denef K. A history of research on the link between (micro) aggregates, soil biota, and soil organic matter dynamics. Soil \& Tillage Research 2004; 79(1): 7-31. http://dx.doi.org/10.1016/j.still.2004.03.008. 
Solly EF, Schöning I, Boch S, Kandeler E, Marhan S, Michalzik B et al. Factors controlling decomposition rates of fine root litter in temperate forests and grasslands. Plant and Soil 2014; 382(1-2): 203-218. http://dx.doi. org/10.1007/s11104-014-2151-4.

Suárez JCS, Bieng MAN, Melgarejo LM, Di Rienzo JA, Casanoves F. First typology of cacao (Theobroma cacao L.) systems in Colombian Amazonia, based on tree species richness, canopy structure and light availability. PLoS One 2018; 13(2): e0191003. http://dx.doi.org/10.1371/ journal.pone.0191003. PMid:29401499.

Vanhove W, Vanhoudt N, Van Damme P. Effect of shade tree planting and soil management on rehabilitation success of a 22-year-old degraded cocoa (Theobroma cacao L.) plantation. Agriculture, Ecosystems \& Environment 2016; 219(1): 14-25. http://dx.doi.org/10.1016/j.agee.2015.12.005.

Velásquez E, Fonte SJ, Barot S, Grimaldi M, Desjardins T, Lavelle P. Soil macrofauna-mediated impacts of plant species composition on soil functioning in Amazonian pastures. Applied Soil Ecology 2012; 56: 43-50. http:// dx.doi.org/10.1016/j.apsoil.2012.01.008.

Velásquez E, Pelosi C, Brunet D, Grimaldi M, Martins M, Rendeiro AC et al. This ped is my ped: visual separation and near infrared spectra allow determination of the origins of soil macroaggregates. Pedobiologia 2007; 51(1): 75-87. http://dx.doi.org/10.1016/j.pedobi.2007.01.002.

Wartenberg AC, Blaser WJ, Gattinger A, Roshetko JM, Van Noordwijk M, Six J. Does shade tree diversity increase soil fertility in cocoa plantations? Agriculture, Ecosystems \& Environment 2017; 248: 190-199. http:// dx.doi.org/10.1016/j.agee.2017.07.033.

Zamudio AM, Carrascal ML, Pulido CE, Gallardo JF, Ávila EA, Vargas MA et al. Métodos analíticos del laboratorio de suelos. 6. ed. Bogotá: Instituto Geográfico Agustín Codazzi; 2006.

Zhang S, Li Q, Lü Y, Zhang X, Liang W. Contributions of soil biota to $\mathrm{C}$ sequestration varied with aggregate fractions under different tillage systems. Soil Biology \& Biochemistry 2013; 62: 147-156. http://dx.doi.org/10.1016/j. soilbio.2013.03.023.

Zhong XL, Li JT, Li XJ, Ye YC, Liu SS, Hallett PD et al. Physical protection by soil aggregates stabilizes soil organic carbon under simulated $\mathrm{N}$ deposition in a subtropical forest of China. Geoderma 2017; 285(1): 323-332. http:// dx.doi.org/10.1016/j.geoderma.2016.09.026. 